\title{
KEPUASAN KERJA SEBAGAI FAKTOR TERBENTUKNYA SIKAP KERJA PEGAWAI NEGERI SIPIL KANTOR KECAMATAN KLAMPIS, BANGKALAN
}

\author{
Arisandi Tri Hardiansyah, Aisyah Amelia, Mila Santika \\ Universitas Trunojoyo Madura
}

\begin{abstract}
This article aims to determine the relationship between organizational job satisfaction which can determine the work attitude of civil servant in the Klampis sub-district office. We conduct interviews by drawing conclusions based on qualitative data and using our perception as authors of every answer that employees provide to us. Out of the total 17 employees, we managed to get answers from 5 employees (due to the limited time) which we were able to use it as a race to determine the level of employee job satisfaction. So that it may not have a big impact for the readers, but can provide information for consideration.
\end{abstract}

Keywords : Job Satisfaction, Work Attitude.

\section{PENDAHULUAN}

Setiap perusahaan mempunyai tujuan yang hendak dicapai dengan efisien dan efektif.Pencapaian tujuan tersebut, dapat dilakukan karena ada berbagai sumber daya yang digunakan dalam melakukan kegiatan perusahaan.Kegiatan yang dilakukan perusahaan tentunya membutuhkan tenaga dan pikiran dari sumber daya manusia.Sumber daya manusia merupakan salah satu faktor penting dalam mencapai tujuan perusahaan.Karyawan sebagai sumber daya dalam perusahaan perlu dikelola dengan baik. Sebagai seorang individu karyawan mempunyai keterbatasan, kebutuhan, keinginan, dan perasaan, sehingga membutuhkan perhatian dan perlakuan khusus dari pada sumber daya perusahaan yang lain.Setiap karyawan akan membandingkan sesuatu hal yang didapat dari perusahaan dengan sesuatu yang diberikannya terhadap perusahaan. Perbandingan tersebut akan menimbulkan persepsi karyawan terhadap pekerjaannya dalam perusahaan. "Persepsi karyawan terhadap suatu hal yang ada di perusahaan akan berdampak pada perasaan, motivasi, sikap, dan perilaku" (Ivancevichetal, 2006:117).

Kepuasan kerja dapat menentukan sikap karyawan terhadap pekerjaannya.Robbins dan Judge (2008:99) berpendapat bahwa "Seseorang dengan tingkat kepuasan kerja yang tinggi memiliki perasaan-perasaan positif tentang pekerjaan tersebut, sementara seseorang yang tidak puas memiliki perasaan-perasaan yang negatif tentang pekerjaan tersebut". Kreitner dan Kinicki (2005:272) berpendapat bahwa "Kepuasan berasal dari persepsi seseorang bahwa output pekerjaan, relatif sama dengan inputnya, perbandingan yang 
mendukung output atau inputlainnya yang signifikan". Input merupakan sesuatu hal yang diberikan karyawan pada perusahaan seperti, tenaga, pikiran, waktu, peralatan pribadi, dan lainlain. Sedangkan output berupa sesuatu yang diperoleh dan dirasakan karyawan dari perusahaan seperti, gaji dan benefit tambahan, hubungan sosial, dan lain-lain. "Kepuasan kerja yang dirasakan karyawan diperoleh dari beberapa dimensi yaitu pekerjaan itu sendiri, imbalan, supervisi, rekan kerja, peluang promosi, kondisi pekerjaan, dan keamanan pekerjaan" (Ivancevichetal, 2007:90). Saat melakukan pekerjaan, karyawan akan menilai pekerjaan yang dilakukannya. Tugas yang dikerjakan tidak menimbulkan kesulitan ataupun kebosanan.Tugas yang dikerjakan sesuai dengan minat, kemampuan, dan pendidikan.Tugas yang dikerjakan menimbulkan rasa senang, kebanggaan, dan memberikan tanggung-jawab.Imbalan merupakan hasil yang mereka terima dari pekerjaan.Imbalan yang diterima karyawan haruslah sesuai dengan beban kerja, jabatan, maupun kebutuhan karyawan. Karyawan juga akan membandingkan imbalan yang mereka terima baik dengan rekan kerja maupun dengan orang lain di perusahaan lain. Perbandingan lainnya yang dijadikan dasar penilaian karyawan juga mengacu pada peraturan pemerintah dan kesanggupan perusahaan dalam memberikan imbalan.Dalam menyelesaikan pekerjaan karyawan membutuhkan rekan kerja yang membantu menyelesaikan pekerjaan. Karyawan akan merasa bergairah dalam bekerja dengan adanya hubungan yang baik dengan rekan kerja dan pimpinanya. Rekan kerja yang memberi dorongan moril, memberikan saran dan nasihat membantu karyawan dalam berprilaku dalam perusahaan. Pengawasan atau supervisi yang memberikan dorongan, membimbing, dan mengarahkan karyawannya agar bekerja sesuai dengan ketentuan perusahaan.Kondisi pekerjaan yang memberikan kenyamanan dan mendukung pekerjaannya, akan membuat karyawan merasa tenang dalam bekerja. Perusahaan yang memberikan kesempatan karyawan untuk maju dalam bekerja baik itu berupa pengetahuan maupun jabatan yang lebih tinggi, akan berdampak pada kepuasan karyawan mengenai kebutuhan akan aktualisasi diri dan dihargai dalam organisasi. Terkait dengan keamanan kerja, karyawan membutuhkan kepastian mengenai status mereka dalam organisasi, status tersebut bisa sebagai pegawai tetap maupun pegawai kontrak yang masih mempunyai peluang bekerja dalam perusahaan.

Sutrisno (2009:79) menyatakan bahwa: Karyawan yang tidak memperoleh kepuasan kerja tidak akan pernah mencapai kepuasan psikologis dan akhirnya akan timbul 
sikap atau tingkah laku negatif dan pada gilirannya dapat menimbulkan frustasi, sebaliknya karyawan yang terpuaskan akan bekerja dengan baik, penuh semangat, aktif dan dapat berprestasi lebih baik dari karyawan yang tidak memperoleh kepuasan kerja.Kepuasan kerja dapat mempengaruhi disiplin kerja karyawan kearah yang lebih baik,disiplin kerja karyawan kearah yang lebih baik,hal ini disebabkan karena karyawan telah mencapai kepuasan psikologis yang memunculkan sikap positif dari karyawan. "Disiplin yang baik mencerminkan besarnya tanggung jawab seseorang terhadap tugastugas yang diberikan kepadanya.Hal ini mendorong gairah kerja, semangat kerja, dan terwujudnya tujuan perusahaan, karyawan, serta masyarakat pada umumnya" (Rivai dan Sagala, 2010:824).

Singodimedjo dalam Sutrisno (2009:91) mengatakan, "Disiplin berasal dari sikap kesediaan dan kerelaan seseorang untuk mematuhi dan mentaati norma-norma peraturan yang berlaku di sekitarnya". Kepuasan kerja yang dicapai karyawan akan mempengaruhi kesediaan dan kerelaan karyawan dalam berdisiplin. Kesediaan dan kerelaan yang diperoleh karyawan akan berdampak pada tingginya disiplin kerja karyawan di perusahaanKepuasan kerja juga berpengaruh kepada komitmen organisasional. Menurut pendapat Mowday dalam Sopiah (2008:163) "Pada fase awal (initialcommitmen) faktor yang mempengaruhi komitmen karyawan pada perusahaan adalah karakteristik individu, harapan karyawan pada organisasi dan karakteristik pekerjaan". Tercapainya harapan karyawan pada perusahaan menimbulkan kepuasan yang pada akhirnya akan mempengaruhi komitmen karyawan terhadap perusahaan. Disiplin kerja dapat mempengaruhi komitmen yang dimiliki karyawan. Stum (1998) mengemukakan bahwa "Arah organisasi merupakan salah faktor yang mempengaruhi komitmen, dimana bukan hanya mengkomunikasikan visi, misi, strategi dan tujuan perusahaan tapi bagaimana mendapatkan komitmen itu tercipta". Simamora (2006:611) mengemukakan bahwa "Aturan disusun untuk tujuan organisasi yang lebih jauh". Disiplin merupakan salah satu cara menumbuhkan komitmen karyawan kepada perusahaan. Dimanadengan adanya kepercayaan dan penerimaan terhadap disiplin kerja dapat mempengaruhi sikap kerja karyawan.

Kantor Kecamatan Klampis merupakan salah satu kantor dinas Pegawai Negeri Sipil Kecamatan Klampis yang berfungsi sebagai sarana pemenuhan kebutahan dan pencatatan sipil masyarakat daerah Klampis.Sebagai perangkat Kecamatan, Kantor 
Kecamatan Klampis tentunya harus melayani masyarakat dengan sebaikbaiknya.Pemberian pelayanan yang baik tentunya tidak lepas dari sumber daya manusia yang ada di Kantor Kecamatan. Disiplin kerja dan komitmen kerja karyawan yang tinggi akan berdampak pada keinginan karyawan untuk berusaha bekerja dengan lebih baik, sehingga dapat memberikan pelayanan kepada masyarakat dengan baik. Kepuasan kerja merupakan salah satu rekomendasi yang dianggap penting dalam mendorong karyawan agar berdisipilin dan berkomitmen terhadap tujuan, visi, dan misi sesuai aturan kenegaraan.Di Area Klampis sering terjadi sengketa tanah yang melibatkan antar masyarakat yang menyebabkan para pegawai Kantor harus mampu turun ke desa atau lapangan untuk ikut menyelesaikannya. Dari masalah tersebut pastinya akan menimbulkan ketidakpuasan jikalau tindakan yang dilakukan lambat atau bahkan tak dapat menyelesaikan masalah. Dalam hal ini, penulis berasumsi disiplin kerja dan komitmen organisasional yang tinggi dapat meningkatkan etos kerja karyawan itu sendiri.Berdasarkan dari pemikiran di atas, maka penuis mengadakan membuat sebuah artikel dengan judul Kepuasan kerja sebagai dimensi penentuan Sikap Kerja Pegawai Negeri Sipil Kantor kecamatan Klampis .

\section{TINJAUAN PUSTAKA}

\section{Pengukuran Kepuasan Kerja}

Robbins dan Judge (2008:98) mendefinisikan "Kepuasan kerja merupakan suatu perasaaan positif tentang pekerjaan seseorang yang merupakan hasil dari sebuah evaluasi karakteristiknya". Martoyo (2007:57) memaparkan "Kepuasan kerja merupakan keadaaan emosional karyawan dimana terjadi ataupun tidak terjadi titik temu antara nilai balas jasa karyawan dari perusahaan/organisasi dengan tingkat nilai balas jasa yang memang diinginkan oleh karyawan yang bersangkutan". Definisi dari Robbin merupakan definisi yang benar-benar luas. Namun, ini melekat pada konsep tersebut.Pekerjaan seseorang lebih dari sekerdar aktivitas mengatur kertas.Maksudnya, setiap pekerjaan menuntut mereka untuk berinteraksi dengan rekan kerja dan atasan-atasan, mengikuti peraturan dan kebijaksanaan-kebijaksanaan organisasional, memenuhi standar-standar kinerja, menerima kondisi-kondisi kerja yang kerap kali kurang ideal, dan lain-lain. Itu artinya bahwa penilaian seorang karyawan tentang seberapa ia merasa puas atau tidak puas dengan 
pekerjaan merupakan penyajian yang rumit dari sejumlah elemen pekerjaan yang berlainan.

Dua pendekatan paling luas digunakan adalah penelitian tunggal secara umum dan nilai penyajian akhir yang terdiri atas sejumlah aspek pekerjaan. Metode penilaian tunggal secara umum sekedar meminta individu untuk merespon sattu pertanyaan, seperti "dengan mempertimbangkan semua hal, seberapa puaskah diri anda dengan pekerjaan anda?". Kemudian, responder menjawab dengan cara melingkari sebuah angka antara 1 sampai 5 yang cocok dari jawaban mereka baik itu dari sangat puas hingga sangat tidak puas, hal ini akan kami bahas di bagian analisis deskripsi.

\section{Teori-Teori Kepuasan Kerja}

Teori kepuasan kerja yang dikemukakan Mangkunegara (2005:120-123) :

1. Teori keseimbangan (equitytheory), teori ini dikembangkan oleh Adams. Wexley dan Yukl dalam mengemukakan komponen utama dari teori ini adalah : Input adalah suatu nilai yang diberikan karyawan saat melaksanakan pekerjaannya, Outcome adalah semua nilai yang diperoleh karyawan dari pekerjaannya, Comparison personadalah seorang pegawai yang berada dalam organisasi yang sama ataupun diluar organisasi, atau dirinya sendiri dalam pekerjaan sebelumnya, Equity - inequity adalah suatu yang dirasakankaryawan adil atau tidak adil.

2. Teori perbedaan (discrepancytheory), teori ini pertama kali dikemukan oleh Porter. Ia berpendapat bahwa mengukur kepuasan kerja dapat dilakukan dengan cara menghitung selisih antara apa yang seharusnya dengan kenyataan yang dirasakan pegawai. Locke (1996) mengemukakan bahwa kepuasan kerja pegawai bergantung pada perbedaan antara apa yang didapat dan apa yang diharapkan oleh pegawai.

3. Teori pemenuhan kebutuhan (needfulfillmenttheory), menurut teori ini kepuasan kerja pegawai bergantung pada terpenuhinya atau tidak nya kebutuhan pegawai.

4. Teori pandangan kelompok (socialreferencegrouptheory), pada teori ini, kepuasan kerja karyawan bukanlah bergantung pada pemenuhan kebutuhan 
saja, tetapi juga bergantung pada pandangan dan pendapat kelompok yang dianggap sebagai kelompok acuan.

5. Teori dua faktor dari Herzberg, berdasarkan teori ini kepuasan kerja dan ketidakpuasan kerja itu terpisah dan berbeda. Teori ini merumuskan dua faktor yaitu satisfiesatau motivators dan dissatisfies atau hygienefactors.

6. Teori pengharapan (expectancytheory), Vroom menjelaskan bahwa motivasi merupakan suatu produk dari bagaimana seorang menginginkan sesuatu, dan penaksiran seseorang memungkinkan aksi tertentu yang menuntunnya".

\section{Faktor penyebab tingginya kepuasan kerja}

Dalam Robbins (2008:119) menyebutkan bahwa sebuah tinjauan bukti mengidentifikasikan empat faktor yang menyebabkan tingginya tingkat kepuasan karyawan yaitu :

1. Kerja yang menantang secara mental.

Pada umumnya individu lebih menyukai pekerjaan yang memberi mereka peluang untuk menggunakan keterampilan dan kemampuan serta memberi beragam tugas, kebebasan dan umpan balik tentang seberapa baik kerja mereka.Karakteristikkarakteristik ini membuat kerja lebih menantang secara mental.

2. Penghargaan yang sesuai.

Karyawan menginginkan sistem bayaran yang mereka rasa adil, tidak ambigu dan selaras dengan harapan-harapan mereka. Ketika bayaran dianggap adil, sesuai dengan tuntutan pekerjaan, tingkat keterampilan individu, dan standar bayaran masyarakat, kemungkinan akan tercipta kepuasan.

3. Kondisi Kerja yang mendukung.

Karyawan berhubungan dengan lingkungan kerja mereka untuk kenyamanan pribadi dan kemudahan melakukan pekerjaan yang baik.Berbagai penelitian menunjukkan bahwa karyawan lebih menyukai lingkungan fisik yang nyaman atau tidak berbahaya.Selain itu, sebagian besar karyawan lebih menyukai bekerja relatif dekat dengan rumah, dengan fasilitas relatif modern dan bersih, serta dengan peralatan yang memadai.

4. Kolega yang suportif. 
Individu mendapatkan sesuatu yang lebih daripada sekedar uang atau prestasi yang nyata dari pekerjaan untuk sebagian besar karyawan, kerja juga memenuhi kebutuhan interaksi sosial.Oleh karena itu tidak mengerankan bahwa memiiki rekan-rekan kerja yang ramah dan suportif mampu meningkatkan kepuasan kerja.Perilaku atasan seseorang juga merupakan faktor penentu kepuasan yang utama.Penelitian mengungkapkan bahwa kepuasan karyawan meningkat ketika pengawas langsung adalah orang yang pengertian dan ramah, memberikan pujian untuk kinerja yang baik, mendengarkan opini-opini karyawan, dan menunjukkan minat pribadi dalam diri mereka.

\section{Dimensi Kepuasan Kerja}

Kepuasan kerja yang dirasakan karyawan dari pekerjaannya diperoleh dari beberapa dimensi menurut Robbins (2008:110) yang menyebutkan : “ Kerja itu sendiri, bayaran/imbalan, promosi, pengawasan, rekan kerja dan keseluruhan". Pada kenyataan kerja kerja itu sendiri erat kaitannya dengan kerja itu sendiri, bayaran, kenaikan jabatan dan hal-hal yang telah disebutkan oleh Robbins.Menikmati kerja itu sendiri hampir selalu berkaitan dengan tingkat kepuasan kerja yang tinggi secara keseluruhan.Pekerjaan menarik yang memberikan pelatihan, variasi, kemerdekaan, dan kendali memuaskan sebagian besar karyawan.Dengan kata lain, sebagian besar individu lebih menyukai kerja yang menantang dan membangkitkan semangat daripada kerja yang dapat diramalkan dan rutin.

\section{Disiplin Kerja}

Sutrisno (2009:92) memaparkan "Disiplin adalah sikap hormat terhadap peraturan dan ketetapan perusahaan, yang ada dalam diri karyawan, yang menyebabkan ia dapat menyesuaikan diri dengan sukarela pada peraturan dan ketetapan perusahaan”. Simamora (2006:610) mendefinisikan "Disiplin merupakan bentuk pengendalian diri karyawan dan pelaksanaan yang teratur serta menunjukkan tingkat kesungguhan tim kerja dalam organisasi”.

\section{Bentuk-Bentuk Disiplin Kerja}

G.R Terry dalam Sukarna (1992:105) yang membagi disiplin menjadi dua bentuk yaitu: (1) Selfimposeddiscipline (disiplin yang timbul dari dirinya) adalah disiplin yang 
timbul dari kesadaran karyawan itu sendiri, karna tugas dan kewajibannya. (2) Comanddiscipline (disiplin berdasarkan perintah) adalah disiplin yang timbul karena adanya peraturan dan sanksi yang diberlakukan di dalam organisasi”.

\section{Pelaksanaan Disiplin Kerja}

Sutrisno (2009:100) memaparkan peraturan-peraturan yang akan berkaitan dengan disiplin itu adalah sebagai berikut: peraturan jam masuk, pulang dan jam istrahat, peraturan dasar tentang berpakaian, bertingkah laku dalam pekerjaan, peraturan cara-cara melakukan pekerjaan dan berhubungan dengan unit kerja lain, peraturan tentang apa yang boleh dan apa yang tidak boleh dilakukan oleh pegawai selama dalam organisasi.

Suatu program disiplin yang konstruktif harus dikembangkan di sekitar elemenelemen penting, menurut Sutrisno (2009:101) adalah sebagai berikut: “(1) Rumusan ketetapannya jelas, aturannya masuk akal, dipublikasikan dan dijalankan secara hati-hati. (2) Pelaksanaannya adil dengan menggunakan peringatan dan hukum yang dimaklumkan, dengan tujuan memberi koreksi, seimbang dengan pelanggaran, tidak keras pada permulaan, dan ditetapkan secara seragam. (3) Kepemimpinan penyeliaan yang disesuaikan pada aturan-aturan pendisiplinan dan prosedur-prosedur, penuh pengertian tetapi teguh dalam menangani masalah pendisiplinan, dan kepemimpinan penyeliaan itu sendiri merupakan suatu contoh bagi prilaku karyawan. (4) Pelaksanaan yang adil dan seragam untuk penyelidikan pelanggaran yang tampak, dimanapelaksanaannya tergantung pada tinjauan tingkat manajemen yang lebih tinggi termasuk cara minta banding terhadap putusan pendisiplinan yang dianggap tidak adil”.

\section{Faktor-Faktor yang Mempengaruhi Disiplin Kerja}

Singodimedjo dalam Sutrisno (2009:94-98) mengemukakan faktor yang mempengaruhi disiplin kerja adalah "besar kecilnya pemberian kompensasi, ada tidaknya keteladanan pimpinan dalam perusahaan, ada tidaknya aturan pasti yang dapat dijadikan pegangan, keberanian pimpinan dalam mengambil tindakan, ada tidaknya pengawasan pimpinan, ada tidaknya perhatian kepada para karyawan, diciptakan kebiasaankebiasaan yang mendukung tegaknya disiplin".Beberapa faktor yang diungkapkan Singodimedjotermasuk ke dalam dimensi-dimensi padakepuasan kerja, sehingga kepuasan kerja juga mempengaruhi disiplin kerja karyawan dalam perusahaan, artinya "jika kepuasan kerja karyawan tinggi semakin tinggi pula disiplin pegawai tersebut. Sebaliknya 
jika kepuasan kerja karyawan rendah maka disiplin pegawai tersebut juga rendah". (Hasibuan. 2009:203; Fathoni. 2006:175).

\section{Komitmen Organisasional}

Mowday dalam Sopiah (2008:155) menyebutkan "Komitmen kerja sebagai istilah lain dari komitmen organisasional. Komitmen organisasional merupakan dimensi perilaku penting yang dapat digunakan untuk menilai kecenderungan karyawan untuk bertahan sebagai anggota organisasi”. Steers dan Black dalam Sopiah (2008:157) mengatakan bahwa: "Karyawan yang memiliki komitmen organisasional yang tinggi dapat dilihat dengan ciri-cirinya yaitu; adanya kepercayaan dan penerimaan yang kuat terhadap nilai dan tujuan organisasi, adanya kesediaan untuk berusaha sebaik mungkin demi organisasi, dan keinginan yang kuat untuk menjadi anggota organisasi”.

\section{Bentuk-Bentuk Komitmen Organisasional}

Meyer etal, dalam Utaminingsih (2014:147-149) menyebutkan tiga bentuk atau komponen dari komitmen organisasional: “(1) Komitmen afektif melibatkan tiga aspek yaitu pembentukan, pengaturan emosi terhadap organisasi, identifikasi, dan keinginan untuk mempertahankan keanggotaan organisasi. (2) Komitmen keberlanjutan merupakan suatu bentuk pengikatan psikologis pada organisasi yang direfleksikan sebagai persepsi pegawai untuk tetap bekerja dalam organisasi. (3) Komitmen normatif merefleksikan perasaan wajib untuk melakukan pekerjaan. Para pegawai dengan tingkat komitmen normatif tinggi merasa sejalan dengan organisasi”.

\section{Proses Terjadinya Komitmen Organisasi}

Minner dalam Sopiah (2008:161) menjelaskan proses terjadinya komitmen organisasional, yaitu: “(1) Pada fase awal (intialcommitment) adalah komitmen yang muncul pada saat awal bekerja di organisasi. (2) Fase kedua (commitmentduringearlyemployment) adalah komitmen yang muncul setelah karyawan bekerja beberapa tahun di organisasi. (3) Fase ketiga (commitmentduringlatercareer) adalah komitmen yang muncul setelah bekerja dalam waktu yang lama dalam organisasi”.

\section{Faktor-Faktor yang Mempengaruhi Komitmen Organisasional}


Stum (1998) mengemukakan lima faktor yang mempengaruhi komitmen karyawan pada organisasi , yaitu: "budaya keterbukaan, kepuasan kerja, kesempatan personal untuk berkembang, arah organisasi, dan penghargaan kerja yang sesuai dengan kebutuhan. Disiplin dapat mempengaruhi komitmen karyawan, semakin tinggi disiplin karyawan akan semakin tinggi pula komitmen karyawan terhadap organisasi (Hapsari, 2007:48). Hunt dan Morgan dalam Utaminingsih (2014:144) mengemukakan "Karyawan memiliki komitmen yang tinggi bila memiliki kepercayaan dan menerima tujuan dan nilai organisasi”. Nilai dan tujuan yang ada di organisasi dapat berupa disiplin kerja, seperti yang diungkapkan Simamora (2006:611), "Aturan disusun untuk tujuan organisasi yang lebih jauh" dan "disiplin mencerminkan mutu moral organisasi dan memberikan arah kepada tindakan bersama" (Black, 1991:152).Berdasarkan pendapat tersebut disiplin dijadikan dasar dalam mengkomunikasikan tujuan dan nilai yang ada di organisasi, sehingga dibutuhkan kepercayaan dan penerimaan karyawan terhadap aturan disiplin kerja.

\section{Sikap Kerja atau Perilaku Karyawan}

Ada konsekuensi ketika karyawan menyukai pekerjaan mereka, dan ada konsekuensi ketika karyawan tidak menyukai pekerjaan mereka. Menurut Robbins (2008:111), sikap kerja seorang karyawan memiliki sebuah kerangka teoritis, kerangka tersebut didefinisikan sebagai berikut :

1. Keluar (exit), Ketidakpuasan yang diungkapkan melalui perilaku yang ditujukan untuk meninggalkan organisasi, termasuk mencari posisi baru dan mengundurkan diri.

2. Aspirasi (Voice), Ketidakpuasan yang diungkapkan melalui usaha-usaha aktif dan konstruktif guna memperbaiki kondisi, termasuk menyarankan perbaikan, mendiskusikan masalah dengan atasan, dan beberapa bentuk aktivitas serikat kerja.

3. Kesetiaan (loyalty), Ketidakpuasan yang diungkapkan dengan secara aktif menunggu membaiknya kondisi, termasuk membela organisasi ketika berhadapan dengan kecaman eksternal dan mempercayai organisasi serta manajemennya untuk melakukan hal yang benar.

4. Pengabaian (neglect), ketidakpuasan yang diungkapkan dengan membiarkan kondisi menjadi lebih buruk, termasuk ketidakhadiran atau keterlambatan 
Perilaku keluar dan pengabaian mencakup variabel-variabel kinerja kita, produktivitas, ketidakhadiran, dan perputaran karyawan.Tetapi model ini mengembangkan respon karyawan untuk mencakup pengaruh dan kesetiaan perilaku konstruktif yang memungkinka individu untuk menoleransi situasi yang tidak menyenangkan atau membangkitkan kondisi kerja yang memuaskan.Hal ini membantu kita memahami berbagai situasi, seperti terkadang dijumpai diantara para pekerja yang membentuk serikat kerja.

\section{METODE PENELITIAN}

Artikel ini bertujuan untuk menjelaskan bagaimana hubungan kepuasan Kerja sebagai penentu sikap kerja pada pegawai Negeri Sipi Kantor Kecamatan Klampis. Observasi yang kami lakukan adalah dengan melakukan tanya jawab dengan beberapa pegawai tetap yang telah bekerja dan mengabdi di Kantor kecamatan tersebut. Metode tanya jawab pun jugakamu tujukan dengan maksud mengetahui lebih dalam bagaimana kegiatan keseharian pegawai dan bagaimana tugas mereka selama bekerja, dengan menggunakan penganalisisan dengan metode pengambilan persepsi, dengan melalui proses interpretasi dan analisis sebab-akibat. Hasil observsi kami sebagai berikut :

\section{HASIL DAN PEMBAHASAN}

\section{Kepuasan Kerja dilihat dari Dimensinya}

Sesuai dengan pembahasan sebelumnya, menyatakan bahwa dimensi kepuasan kerja itu meliputi beberapa hal yaitu Kerja itu sendiri, bayaran/imbalan, promosi, pengawasan, rekan kerja dan keseluruhan. Penulis mencoba menggali bagaimana Kepuasan kerja pegawai jika dilihat dari 5 hal tersebut. Pembaca mungkin mengetahui bahwa bayaran kerap kali diutarakan ketika mendiskusikan kepuasan kerja.Hal tersebut pula yang menjadi pokok pembicaraan kami dengan beberapa pegawai. Mereka beranggapan bahwa kebutuhan mereka akan bayaran atau gaji menjadi penentu kepuasan kerja mereka selama ini. Seperti salah satu responden "saat kami bekerja maka yang kami pikirkan adalah kapan gaji kami cair, dan beberapa tunjangan lain dari setiap kegiatan di Kantor akan memotivasi kami”.

Hal tersebut menjadi pembicaraan yang lebih meluas dengan pembahasan tentang bagaimana gaji menjadi motivasi karena mereka btuh memenuhi kebutuhan sehari-hari. 
Responden lain menyebutkan bahwa saat mereka sedang melakukan banyak tugas di kantor bahkan harus pergi ke desa-desa dan lapangan maka akan membuat mereka merasa letih dan malas, namun mereka berusaha sebaik mungkin untuk menyelesaikannya karena ada tanggungan disana dan itu adalah bentuk pertanggungjwaban terhadap gaji yang mereka terima.

Responden lain lebih menyebutkan masalah pertanyaan bagaimana pekerjaan di kecamatan bisa memberikan kepuasan kerja, dan mereka pun memberikan pandangan bahwa pekerjaan di kantor kecamatan seperti mereka tidaklah terlalu sibuk, mereka hanya mengurus urusan sipil yang biasa mereka hadapi dan tak ada tantangan berarti selama menjalaninya. Responden beranggapan menjadi seorang PNS adalah pilihan yang tepat bagi mereka yang tak ingin terlalu memiliki pekerjaan yang berisiko, dengan kata lain pekerjaan mereka termasuk pekerjaan yang bisa di anggap aman dan tak terlalu menguras tenaga serta pikiran meskipun adakalanya hal tersebut terjadi, namun tak sesering dengan kantor-kantor yang bergerak di bidang usaha atau pekerjaan lainnya. disisi lain kami juga menanyakan apakah para pegawai banyak yang memiliki obsesi untuk naik jabatan untuk memuaskan keinginan mereka dalam konteks kerja, dan jawaban mereka adalah ada namun tak banyak. Sistem promosi jabatan menurut mereka tidaklah mudah, karena mereka bekerja untuk instansi pemerintah maka segala kegiatan mereka diatur oleh pusat bahkan kerap kali sistem promosi bukan hanya ditentukan oleh seberapa giat dan kompetennya pegawai bekerja tetapi juga karena adanya koneksi dan uang.

Salah satu sumber menyebutkan bahwa fase pegawai negeri Sipil itu butuh proses yang panjang, mereka lulus dan masuk menjadi PNS harus melalui beberapa golongan dan menurut mereka kepuasan pegawai kebanyakan saat mereka mampu mencapai Golongan III, karena kembali lagi mereka lebih termotivasi dengan gaji dan tunjangan-tunjangan yang ditawarkan. Namun, bagi mereka yang memiliki ambisi dan keinginan kuat untuk mencapai puncak, butuh persiapan yang besar dengan harus memiliki banyaknya koneksi, serta kadangkala ada nominal tertentu yang mereka sebutkan yang tak ingin mereka bahas lebih lanjut lagi.

Selanjutnya tak hanya sampai di situ, kami juga menanyakan bagaimana sistem pengawasan atasan contohnya camat dengan kegiatan kantor kecamatan. Mereka pun membeberkan bahwa kebanyakan dari mereka menyebutkan bahwa camat atau perangkat utama di kecamatan tidak terlalu mengekang mereka untuk bekerja, pengawasan pun tak se 
ketat dan sesering jenis kantor komersil, karena sejatinya pengawasan setiap devisi untuk beberapa kegiatan akan langsung berhubungan dengan kedinasan kota, salah satunya bagian Keuangan yang menyebutkan salah satu contoh nya adalah Raskin (beras Miskin), dimana pelaporan segala kegiatan baik penyaluran, penyimpanan dan seluruh kegiatan langsung melakukan laporan ke dinas Bulog Kabupaten, meskipun pada akhirnya dengan taken dan persetujuan Camat kantor. Sama halnya dengan kegiatan lainnya di bagian keuangan yang menyebutkan bahwa salah satu tugasnya adalah mengurus tentang gaji pegawai, mereka menyebutkan bahwa mereka tak memerlukan pengawasan lagi dari atasan kantor karenapengalokasian gaji akan langsung dari pusat melalui bank terkait sedangkan pekerjaan mereka yang berhubungan dengan pengawasan camat hanya sekedar formalitas pengarsipan dan laporan berkas pegawai.

Pembahasan lain pun bergeser tentang bagaimana lingkungan karyawan atau lebih tepatnya rekan kerja terhadap kepuasan kerja karyawan. Mereka pun memberikan pemahaman bahwa pasti ada beberapa rekan kerja yang memang cocok dengan mereka, tetapi ada juga beberapa karyawan yang disebut bandel atau susah diatur hingga jarang hadir setiap harinya. Namun, mereka kebanyakan memandang bahwa dengan bekerja seperti itu saja dengan beberapa orang yang cocok dapat memberikan kenyamanan bagi mereka, sudah membuat mereka puas untuk bekerja di Kantor tersebut. Jadi sesuai dengan observasi yang kami lakukan dengan melakukan metode persepsi maka kami mencoba menyimpulkan berdasarkan kesan dan impresi kami selama melakukan tanya jawab dan kami percaya bahwa sebagian besar dari mereka merasa sudah puas dengan pekerjaan mereka. Karena kebanyakan dari responden kami tak terlalu berambisi untuk promosi dan mereka pun bersyukur dengan gaji dan berbagai tunjangan meskipun setimpal dengan pekerjaannya, mereka juga menyebut bahwa mereka merasa nyaman berada di zona aman, menunjukkan indikasi bahwa sebagian responden Pegawai egeri Sipil Kecamatan Klampis, Kabupaten Bangkalan memiliki Kepuasan Kerja yang baik.

\section{Kepuasan Kerja Terhadap Disiplin Kerja}

Dari hasil pengolahan data yang didapat dari observasi yang telah dilaksanakan di Kantor Kecamatan Klampis, Bangkalan.variabel kepuasan kerja mempunyai pengaruh yang positif dan signifikan terhadap disiplin kerja. Sehingga dapat dikatakan bahwa kepuasan kerja yang diperoleh karyawan mempengaruhi tingkat disiplin kerja 
karyawan.Hal ini sesuai dengan pendapat Hasibuan (2009:203) yang menyatakan bahwa "jika kepuasan kerja karyawan tinggi semakin tinggi pula disiplin kerja karyawan begitu juga bila sebaliknya". Maryadi (2012) dalam penelitiannya menyebutkan bahwa "ada pengaruh positif dan signifikan dari kepuasan kerja terhadap disiplin kerja".Kepuasan kerja diukur melalui beberapdimensi yaitu pekerjaan itu sendiri, imbalan, supervisi, rekan kerja, peluang promosi, dan kondisi kerja. Meningkatkan dimensi-dimensi kepuasan kerja dapat meningkatkan disiplin kerja karyawan. Hal ini dikarenakan dimensi tersebut dirasakan pegawai melalui pengalamannya selama berada di organisasi, jika ada kepuasan kerja maka ada perasaan-perasaan positif yang timbul di diri karyawan sehingga ia akan bersikap positif terhadap pekerjaannya. Sikap positif tersebut akan berdampak pada disiplin kerja karyawan yang tinggi.

Sebagai contoh salah satu pegawai yang tak ingin disebutkan identitasnya mengatakan bahwa memang sangat benar bahwa saat seseorang merasa puas dan memiliki motivasi di kantor, maka mereka akan lebih disiplin saat bekerja, berbeda dengan dirinya yang kehilangan gairah dan motivasi atau kepuasan kerjanya sehingga ia menjadi pegawai yang tak disiplin. Hal ini dikarenakan tanggungannya di Bank,dari informasi yang kami dapat pegawai tersebut melakukan peminjaman uang ke bank dengan angsuran pembayaran melalui pemotongan gaji karyawan tersebut namun anehnya gaji nya saat ini malah tak bersisa dan malah minus, yang artinya bukan menerima gaji dia harus membayar angsuran tambahan untuk melunasi pinjaman banknya untuk jangka waktu kedepan. Hal ini menyebabkan pegawai tersebut mersa tak puas dengan pekerjaannya. Ia menyebut kembali bahwa sebenarnya pengaruh gaji atau bayaran amatlah penting bagi mereka para pegawai dari golongan kecil, mereka yang sudah tak memiliki gaji akan hilang kemauan untuk disiplin dan bahkan akan sering tak hadir di kantor.

Berbeda dengan seorang sekretaris camat, ia menyebut bahwa posisi atau jabatan serta gaji dan tunjangan yang ia terima menjadi pemicu ia untuk lebih giat untuk masuk dan taat aturan. Ia menyebut kepuasan atas kedudukannya di kantor membuat dia malu jika harus menjadi tidak disiplin. Bukan hanya malu dengan persepsi karyawan lain terhadap dirinya, tetapi dia juga malu terhadap Tuhan yang telah memberinya banyak rezeki, sehingga ia akan berpikir dua kali atau lebih untuk tidak disiplin. Dari kasus tersebut akan membuktikan teori yang dijelaskan Hasibuan bahwa Semakin tinggi tingkat Kepuasan Karyawan maka akan semakin tinggi pula tingkat disiplin kerja mereka. 


\section{Kepuasan Kerja Terhadap Komitmen Organisasional}

Hasil analisis data yang dilakukan, ditemukan hasil bahwa kepuasan kerja berpengaruh secara positif dan signifikan terhadap komitmen organisasi.dapat diartikan semakin tinggi kepuasan kerja karyawan semakin tinggi pula komitmen organisasional karyawan. Hal ini sesuai dengan penelitian Kurniawan (2010) yang menyatakan bahwa "ada pengaruh yang signifikan dari variabel kepuasan kerja terhadap variabel komitmen organisasional”. Hal senada juga dikemukan Sholihah (2011) “ ada pengaruh yang signifikan dari varibel kepuasan kerja terhadap komitmen organisasional".Spector (dalam Sopiah, 2008:157) mengemukakan bahwa "komitmen pada organisasi sangat ditentukan oleh pertukaran kontribusi yang dapat diberikan perusahaan terhadap anggota organisasi dan anggota pada organisasi”. Dimana semakin besar kesesuaian pertukaran yang didasari pandangan karyawan maka semakin besar pula komitmen mereka terhadap perusahaan. Dalam hal ini pertukaran yang diberikan perusahaan dapat berupa imbalan, kesempatan promosi, pekerjaan itu sendiri, kondisi kerja, supervisi, dan rekan kerja. Pertukaran tersebut jika sesuai dengan pandangan karyawan maka akan menimbulkan kepuasan kerja sehingga dapat meningkatkan komitmen karyawan terhadap perusahaan.

Hal ini sesuai dengan pembahasan kita sebelumnya dimana saat kita membandingkan kasus pegawai tak disiplin dan pegawai disiplin, yaitu Pak tajul.Beiau adalah salah satu contoh karyawan yang kuat dengan komitmennya. Untuk mengulas kembali mengenai komitmen, maka harus mengerti dulu apa itu komitmen organisasional. Seperti di awal dijelaskan bahwa Komitmen organisasional menurut Mowday dalam Sopiah (2008:155) menyebutkan "Komitmen kerja sebagai istilah lain dari komitmen organisasional. Komitmen organisasional merupakan dimensi perilaku penting yang dapat digunakan untuk menilai kecenderungan karyawan untuk bertahan sebagai anggota organisasi".Saat kita menelaah lagi penjabaran tersebut maka beberapa karyawan di Kantor Kecamatan Klampis memiliki Komitmen organisasional yang baik meskipun dalam tanda kutip mereka berkomitmen hanya untuk berada dalam zona nyaman.

Sama dengan pak Tajul, beliau bisa disebut seseorang yang memiliki komiten organisasi karena beliau memiliki pandangan untuk bertahan dan meneruskan kegiatan 
dalam organisasinya sebaik mungkin.Seperti hal nya yang telah disebutkan Pak Tajul dirasa memenuhi bentuk-bentuk dari komitmen organisasional yang meliputi "(1) Komitmen afektif melibatkan tiga aspek yaitu pembentukan, pengaturan emosi terhadap organisasi, identifikasi, dan keinginan untuk mempertahankan keanggotaan organisasi. (2) Komitmen keberlanjutan merupakan suatu bentuk pengikatan psikologis pada organisasi yang direfleksikan sebagai persepsi pegawai untuk tetap bekerja dalam organisasi. (3) Komitmen normatif merefleksikan perasaan wajib untuk melakukan pekerjaan. Para pegawai dengan tingkat komitmen normatif tinggi merasa sejalan dengan organisasi”.

Selain itu ada beberapa karyawan pula yang memang sudah memiliki komiten organisasional, saat kami bertanya apakah ada niatan untuk berpindah profesi atau resign dari pekerjaannya saat ini, hampir semua dari mereka menjawab tidak. Hal itu karena alasan mereka yang sederhana, yaitu kami sudah puas untuk bekerja seperti ini.Maka sudah dipastikan bahwa kepuasan kerja sangat mempengaruhi komitmen organisasional seseorang. Mereka yang sudah merasa puas dengan pekerjaannya akan meresa bahwa setiap pekerjaan yang telah ia jalani bersama organisasinya saat ini adalah tanggung jawab besar dan sudah sepantasnyalah untuk meneruskan dan menjalankannya sebaik mungkin. Maka teori bahwa semakin tinggi tingkat kepuasan kerja seseorang, maka semakin tinggi Komitmen organisasional orang itu pula, berlaku di lingkungan kerja Kantor Kecamatan Klampis, Bangkalan.

\section{Kepuasan Kerja Terhadap Ketidakhadiran}

Kita menemukan suatu hubungan negatif yang konsisten antara kepuasan dan ketidakhadiran, tetapi korelasi tersebut berkisar antara sedang sampai lemah. Dalam buku Robbins (2008:116) menyebutkan hal lebih masuk akal jika karyawan yang tidak memiliki kepuasan kerja akan cenderung melalaikan pekerjaannya. Seperti yang dijelaskan sebelumnya kepuasan kerja itu adalah suatu dorongan positif dimana mereka akan memberikan dampak positif pula. Hal inilah yang coba diterangkan kami bahwa hubungan keduanya adalah korelasi negatif, namun ada kalanya seseorang yang tak hadir bukan karena tidak puas dengan kinerjanya, karena akan ada faktor-faktor lain yang terjadi sehingga hubungan keduanya bukanlah korelasi negatif yang kuat, tetapi korelasi negatif yang sedang. Sebagai contoh seperti kasus salah satu pegawai Kantor kecamatan yang sudah dijelaskan pada pembahasan dimensi kepuasan kerja.Pegawai tersebut melakukan 
pinjama hingga anggsurannya memotong dari gajinya hingga gajinya dalam nominal minus. Hal ini akan menyebabkan kepuasan kerjanya menurun dan akan berdampak pada hilangnya motivasi untuk bekerja, tak ada lagi yang namanya rasa untuk ingin bertahan, atau hiangnya rasa memiliki seseorang sehingga akan berdampak pada beberapa aktivitasnya di kantor terganggu, seperti sering tidak hadirnya di kantor. Dari kasus ini mutlah hal tersebut dipengaruhi oleh rasa kepuasan kerjanya yang menurun.

Disisi lain, kami menemukan seorang karyawan di Kantor Kecamatan Klampis itu pula yang sering absen dari pekerjaannya, yang setelah kami mencoba cari tahu beliau juga memiliki usaha rumah makan di Kota, hal tersebut membuatnya memiliki kesibukan lain yang banyak menyita waktunya sehingga dia jarang hadir din kantor. Lalu apakah karyawan tersebut karena kurang puas dengan pekerjaannya ?jawabannya tidak, saat di tanya karena kebetulan kami bertemu dengannya ia berkeluh kesah bahwa ia sudah amat nyaman bekerja di instansi kecamatan itu, meskipun gajinya tidak seberapa tetapi ia merasa senang saat melakukan tugas kantornya, lalu apa penyebab beliau melakukan usahanya tersebut ? itu karena beliau mencoba untuk membantu saudaranya yang sedang mau membuka usaha tersebut, namun ternyata usahanya berjalan baik hingga ia pun mau tidak mau ikut andil dalam kegiatan usaha tersebut.

Hal ini menjelaskan bahwa tidak selalu hubungan Kepuasan Kerja berkorelasi negatif kuat terhadap kehadiran seorang karyawan, karena terdapat berbagai faktor lain yang mendorong individu harus mengesampingkan pekerjaan yang membuatnya merasa nyaman hanya untuk keadaan mendesak tertentu.

\section{Kepuasan Kerja sebagai faktor penentu Perilaku Menyimpang di tempat Kerja}

Faktanya, ketidakpuasan kerja memproduksi banyak perilaku khusus termasuk upaya pembentuka serikat kerja, penyalahgunaan hakikat, pencurian di tempat kerja, pergaulan yang tidak pantas, kelambanan serta sikap malas.Dalam buku Robbin (2008) menyebutkan bahwa perilaku menyimpang di tepat kerja adalah indikator dari sebuah sindrom yang lebih luas yang kita sebut penyimpangan di tempat kerja. Pada observasi kami kali ini, kami juga mencoba untuk menanyakan beberapa hal terkait dengan perilaku pegawai dari kantor itu. Jika dalam buku Robbins menyebutkan bahwa seseorang yang terlalu banyak memberdayakan tempat kerja demi kepentingan pribadinya disebut penyimpangan, maka kami tidak menemukannya di kantor kecamatan Klampis. Bukan 
karena tidak ada perilaku seperti yang disebutkan tadi, tetapi perilaku tersebut tidak lagi dianggap menyimpang oleh karyawan kantor, atau bahkan mereka hampir seluruh karyawan melakukan hal yang sama mengenai eksploitasi ketersediaan barang kantor.

Hal yang paling mencolok di kantor tersebut adalah saat banyaknya pegawai yang memanfaatkan waktu istirahat mereka untuk bermain dengan hanphone mereka, seperti menonton Youtube, bermain game online dan sebagainya. Memang tak terlihat aneh sedikitpun namun jika diperhatikan lagi mereka melakukan hal tersebut menggunakan komputer kantor, jaringan Wifi kantor, dan melakukan kegiatan tersebut pada saat jam istirahat. Hal ini akan dianggap penyimpangan bagi Robben karena sejatinya inventaris kantor dan segala hal yang ada di Kantor digunakan hanya untuk kepentingan kantor, tetapi di kantor kecamatan ini berbeda, mereka bahkan melakukan seluruh kegiatan itu tanpa rasa bersalah karena dirasa sebagai hal yang lurah untu dilakukan.

Saat mereka di tanya apakah mereka setuju bahwa jika seorang pegawai merasa tidak puas dengan kerjanya apakah mereka akan mengakibatkan penyimpangan di tempat kerja? Dan jawaban mereka adalah benar sekali, mereka pun memberikan contoh terkait banyaknya koruptor di luar sana. Mereka beranggapan bahwa ketidakpuasan itu berwujud kurangnya rasa syukur mereka terhadap tuhan yang memberikan rezeki hingga melakukan penyimpangan di tempat kerja.Meskipun hasil observasi ini sesuai dengan berbagai teori yang ada namun, masih terdapat banyak kejanggalan yang membuat kami tidak bisa menduga dan menyimpulkan bagaimana persepsi karyawan di Kantor Kecamatan Klampis tentang suatu perilaku menyimpang di Tempat kerja.

\section{Timbal Balik korelasi seorang Manajer menciptakan Kepuasan Kerja Karyawan}

Pendapat bahwa manajer dan organisasi mampu mengendalikan tingkat kepuasan kerja pada dasarnya adalah menarik. Hal ini sangat sesuai dengan pandangan bahwa secara langsung mempengaruhi proses organisasional dan hasilnya. Sayangnya tak sedikit yang menanmpik peran penting manajer sebagai pembentuk kepuasan Kerja. Seperti responden di kantor Kecamatan Klampis, saat kami tanya apakah pak Camat sebagai pemimpin atau manajer di instansi ini mempunyai peran untuk menimbulkan kepuasan kerja, dan jawaban mereka pun terpecah menjadi dua kubu, ada yang berkata iya dan ada yang berkata tidak. Mereka yang berkata iya menjelaskan bahwa seorang pemimpin itu identik dengan tokoh penggerak, dalam fungsi manajemen pun seorang pemimpin contohnya camat adalah 
tokoh yang disegani dan dipatuhi sebagai atasan, saat pak camat mampu mempengaruhi dan memberikan keleluasaan kepada mereka dan bisa memberikan kenyamanan saat berada di lingkungan kerjanya, secara otomatis kami sudah merasa nyaman dan puas untuk bekerja bersama para Camat. Namun, tak semua Camat dapat melakukan hal tersebut. Salah satu responden menyebut bahwa ia telah bekerja di kantor kecamatan itu lebih dari 15 tahun dan ia telah melalui beberapa masa dengan perubahan seorang Camat. Seiring berlalunya waktu ada beberapa camat yang mampu memberikan motivasi pada pegawainya, tetapi ada pula yang memiliki predikat kurang baik selama kepemimpinannya.Hal tersebut tentu mengakibatkan perbedaan secara harfiah dan secara kenyamanan. Mereka menyebutkan mereka akan puas dengan pekerjaan mereka saat sang manajer (Camat) tak segan memuji saat pekerjaan mereka baik, menegur dan mengoreksi saat pekerjaan mereka kurang baik dan yang paling penting loyal terhadap karyawan tanpa mendeskriminasi. Kembali lagi setelah kami pahami bahwa sifat pegawai di kecamatan tersebut menganggap bahwa kepuasan kerja berhubungan langsung dengan nilai materil.

Berbeda dengan para pegawai yang menjawab Tidak tentang adanya korelasi dengan Kepuasan kerja dengan pengaruh manajer. Pegawai tersebut menyatakan bahwa dirinya tidak sedikitpun tak terpengaruh dengan silih bergantinya Camat, silih bergantinya sikap kepemimpinan mereka dan ia merasa tak ada masalah dengan bagaimana para camat bersikap dan bertindak, ia menyebut bahwa hubungan paling benar adalah ketika mereka sudah merasa nyaman dengan pekerjaan mereka dan tak ada lagi penambahan beban bagi mereka sudah memberikan kepuasan kerja tersendiri bagi mereka.

Dari pernyataan-pernyataan di atas kami mencoba menarik garis besar bahwa Karyawan di Kantor Kecamatan Klampis tak sepenuhnya selaras dengan teori para pakar yang menyebut Kepuasan kerja yang berhubungan dengan pemenuhan kepuasan diri atau eksistensi. Jika secara umum di lihat, sangat sedikit pegawai yang menganggap kepuasan kerja datang saat mereka telah menaklukkan zona nyaman mereka, tetapi kebanyakan pegawai di Klampis menganggap kepuasan kerja bersumber dari kenyamanan mereka bekerja, materil yang mereka dapatkan dan lingkungan kerja mereka yang harmonis. Itu berarti bisa memperlihatkan minimnya persaingan tak sehat untuk pemenuhan kepuasan kerja mereka, sehingga kami dengan mudah menyimpulkan bahwa sebagian besar pegawai Negeri Sipil Kecamatan Klampis sudah merasa puas dengan pekerjaan mereka, yang bisa 
dilihat dari sikap dan perilaku mereka di kantor yang sudah menganggap kantor adalah tempat lain dari rumah mereka.

\section{KESIMPULAN DAN SARAN}

\section{Kesimpulan}

1. Hasil wawancara memperlihatkan Korelasi Kepuasan Kerja yang bersifat positif terhadap disiplin kerja, yang menyatakan bahwa semakin tinggi tingkat kepuasan pegawai Kecamatan Klampis, maka akan semakin disiplin mereka terhadap semua regulasi yang berlaku, yang disebabkan oleh beberapa faktor yaitu kerja itu sendiri, bayaran, promosi, pengawasan, serta rekan Kerja.

2. Selanjutnya observasi kami menujukkan bahwa Kepuasan Kerja mempengaruhi Komitmen kerja, hal ini ditunjukkan dengan beberapa pegawai yang telah memiliki kedudukan cukup tinggi di Kantor kecamatan, mengaku puas dengan pekerjaan yang dijalaninya sehingga menganggap bahwa bertahan dengan pekerjaannya adalah hal terbaik, sehingga sesuai dengan bentuk Normatif Komitmen organisasi, maka korelasi hubungan Kepuasan Kerja dengan komitmen organisasional berhubungan positif.

3. Hasil pengamatan kami menunjukkan bahwa para pegawai Kantor sipil kecamatan Klampis menganggap penyimpangan kerja berbeda dengan teori yang telah biasa kita pelajari. Pada pengamatan kami kegiatan yang seharusnya tergolong menyimpang bisa dianggap lumrah karena kebiasaan yang ada di tempat kerja, salah satu contohnya adalah eksploitasi perlengkapan kantor untuk kepentingan pribadi.

\section{Saran}

Diharapkan mampu mempertahankan kepuasan kerja seluruh pegawai.Karena variabel kepuasan kerja mempunyai pengaruh yang signifikan terhadap disiplin kerja dan komitmen organisasional.Hal tersebut dapat dilakukan melalui pensejahteraan karyawan dari bidang materil khusunya gaji.Karena gaji atau bayaran baik berupa tunjangan memiliki pengaruh besar untuk mendorong kepuasan kerja pergawai Kantor Kecamatan Klampis. Selain itu dnegan kondisi ekonomi dan kebutuhan karyawan yang tak terbatas 
maka akan membuat pegawai lebih bergantung pada bayaran mereka sebagai perwujudan kepuasan kerja mereka. Selain itu dalam meningkatkan disiplin kerja perlu adanya ketegasan , pengawasan dan supervisi dari kantor pusat untuk lebih mengontrol kegiatan kantor karena mereka bekerja untuk memenuhi kebutuhan masyarakat setempat khususnya dalam bidang catatan sipil.

\section{DAFTAR PUSTAKA}

Hasibuan, Malayu S.P. 2009. Manajemen Sumber Daya Manusia. Edisi Revisi, Jakarta : PT. Bumi Aksara.

Ivancevich, J.M., Konopaske, Robert, dan Matteson, Michael T. 2007.Perilaku Manajemen Organisasi, Penerjemah Gania Gina. Edisi ketujuh Jakarta : Erlangga.

Robbins, S.P, Timothy, A.J. 2008.Organizational Behavior (Perilaku Organisasi.Angelica D, penerjemah.Jakarta : Salemba Empat. Terjemahan dari : Pearson Education.

Luthans, F. 2006. Organization Behavior (Perilaku Organisasi. Yuwono, VA, penerjemah. Yogyakarta : ANDI. Terjemahan dari : The McGraw-Hill Companies.

Kurniawan, Denie. 2010. Pengaruh Kepuasan Kerja Terhadap Komitmen Karyawan (studi pada karyawan AJB Bumiputera 1912 kantor cabang Kayutangan Malang). Malang: Universitas Brawijaya.

Ilahi, D.K., Mukzam, M.D., Prasetya, A. Maret 2017. Pengaruh Kepuasan Kerja Terhadap Disiplin Kerja dan Komitmen Organisasional. Jurnal Administrasi Bisnis (JAB), vol 44 no. 1. Hal.31-39. 